\title{
Cut foliage: potentiality of native Argentine ferns as new ornamental crops
}

\author{
Gabriela Facciuto $^{1}$ (D), Maria Julia Pannuzio ${ }^{1}$ (D), Analía Puerta ${ }^{1}$ (D), Marcela Inés Sanchez ${ }^{2}$ (D)
}

${ }^{1}$ Instituto de Floricultura, INTA, Buenos Aires, Argentina.

${ }^{2}$ Jardín Botánico “Arturo E. Ragonese”, Instituto de Recursos Biológicos, INTA, Buenos Aires, Argentina.

\begin{abstract}
The cut foliage constitutes an important part of the floricultural production since it represents a fundamental element in flower arrangements, and ferns are the complementary elements most used by florists. In Argentina, there is native material that has not been yet domesticated and could have suitable characteristics for foliage use. The objective of the work was to determine the potential use of 15 native ferns as cut foliage through quality parameters and vase life, generating a scoring system that allows a classification list. Morphological descriptors such as petiole length, length and width of the blade, planes in which the fronds are arranged, brightness, consistency, abundance of spores and presence of pests were taken into account. Also, the production of fronds of six selected species with good scores was recorded. The results showed that it is feasible to consider the commercial production of Pityrogramma calomelanos, Niphidium crassifolium, Campyloneurum nitidum, Blechnum austrobrasilianum and Pteris denticulata by the quantity of fronds obtained and their quality, represented by their size. Campyloneurum nitidum excelled for its vase life of more than 26 days and frond production of 273.61 fronds $\mathrm{m}^{-2}$ at second year cultivation. Pteris denticulata produces 179.44 fronds $\mathrm{m}^{-2}$ but vase life was only 7 days.
\end{abstract}

Keywords: foliage, frond production, native ferns, new crops, vase life.

\section{Resumo}

Folhagens de corte: potencialidade de samambaias nativas da Argentina como novas culturas ornamentais As folhagens de corte constituem um segmento importante da floricultura, pois representam um elemento fundamental nos arranjos florais, sendo as samambaias os elementos complementares mais utilizados pelos floristas. Na Argentina, existe material nativo, ainda não domesticado, que poderia apresentar características adequadas para o uso como folhagem de corte. $\mathrm{O}$ objetivo do trabalho foi determinar o potencial de utilização de 15 samambaias nativas como folhagem de corte por meio de parâmetros de qualidade e vida de vaso, gerando um sistema de pontuação que permite uma lista de classificação. Foram considerados descritores morfológicos como comprimento do pecíolo, comprimento e largura da lâmina, planos de disposição das frondes, brilho, consistência, abundância de esporos e presença de pragas. Além disso, foi registrada a produção de frondes de seis espécies selecionadas com boas pontuações. Os resultados mostraram que é viável considerar a produção comercial de Pityrogramma calomelanos, Niphidium crassifolium, Campyloneurum nitidum, Blechnum austrobrasilianum e Pteris denticulata pela quantidade de folhas obtidas e sua qualidade, representada pelo tamanho. Campyloneurum nitidum se destacou por sua vida de vaso superior a 26 dias e pela produção de 273,61 folhas $\mathrm{m}^{-2}$ no segundo ano de cultivo. Pteris denticulata produziu 179,44 folhas $\mathrm{m}^{-2}$, porém a sua vida de vaso foi de apenas 7 dias.

Palavras-chave: folhagens, produção de folhas, samambaias nativas, novas culturas, vida de vaso.

\section{Introduction}

The cut foliage constitutes an important part of the floricultural production since it represents a fundamental element in flower arrangements. Despite of this, very few species are available and in low quantities in the Argentinian flower market.
Within the cut foliages, ferns are the complementary elements most used by florists worldwide (Stamps, 2007). The most commercially important fern species and genera are: Rumohra adiantiformis, Adiantum, Cyrtomium, Nephrolepis, Platycerium, Polystichum and Pteris. Lesser important are Davallia and Polypodium. The most popular species globally is $R$. adiantifolia, because it has a vase life

"Corresponding author: facciuto.gabriela@inta.gob.ar

https://doi.org/10.1590/2447-536X.v27i4.2398

Received: May 17, 2021 | Accepted: Aug 27, 2021 | Available online: Sept 10, 2021

Licensed by CC BY 4.0 (https://creativecommons.org/licenses/by/4.0/)

Area Editor: Elisabeth Regina Tempel Stumpf 
of 3 to 4 weeks (Benavente-Garcia et al., 1998). It is also the most commercialized fern in Argentina and is extracted from the wild.

The popularity of ferns for using as cut foliage is due to the availability, consumer acceptance, low cost, and longevity of fronds. The cut flower has been the protagonist within the arrangements, but its importance has been diminishing in favour of the accompanying elements (Gutiérrez et al., 2007). Even in floral design, arrangements also are made using foliage, without any type of flowers, a trend that favours the importance of foliage production. In addition, ferns can be grown as one of the horticultural crop of ornamental value on unutilized geographical regions to bring the unused soil under cultivation (Singh and Johari, 2018). Ferns also have been in use for food, as ornamental plants, valuable unexplored chemicals and for the phytoremediation of contaminated soils providing ecological services (Kumar and Fernandez, 2019; Anderson, 2021).

The Floriculture Institute has started a project for the domestication and use of native ferns for ornamental purposes in order to collaborate in the diversification of production and also, to reduce extractive use (Facciuto et al., 2014). This situation is aggravated when very little information is available about the sustainability of the extractive activities.

In Argentina, ferns comprise 28 families, 91 genera and 366 species distributed in four regions: the Yungas cloudforest, the Andean-Patagonian rainforest and the Pampas Hills (Ponce et al., 2002). This floristic richness creates an opportunity for diversification the production and to provide new textures and shapes for floral art.

There is no single methodology to determine the ornamental potential of a new species, but, before it is launched on the market, it is necessary to identify it taxonomically, to find out the propagation and cultivation methods and objectively determine its ornamental value.
Stumpf et al. (2007) tested the ornamental potential of 11 species native to Rio Grande do Sul, Brazil, as a sum of scores given to ten traits chose by their importance for the floral art and for the market. Also, BeckmannCavalcante et al. (2017) evaluated ornamental potential of native species through a score system considering features of interest for floral art and consumer market. Sankar et al. (2019) evaluated 11 ferns native to India considering quantitative and qualitative characters to classify them and stablished their suitability for landscapes and commercial uses. Safeena et al. (2019) also in India, reflect the aptness of different cut foliages to function for various purposes in floristry through the evaluation of morphological characteristics and vase life of 18 species including ferns and Asparagus species.

In Argentina, there is native material that has not yet been domesticated and could have characteristics suitable for foliage use. Some basic parameters to optimize its production, harvest and handling are the propagation, its storage and postharvest life of the fronds (Stamps, 2007).

The objective of this work was to determine the potential use of native Argentine ferns as cut foliage through quality parameters and vase life. From these results, it is intended to value genetic resources to be considered as new crops for ornamental horticulture.

\section{Materials and Methods}

Fifteen species of ferns native to Argentina were studied. They were grown in a greenhouse with a minimum temperature control of $15^{\circ} \mathrm{C}$ in Floriculture Institute, INTA (Table 1). The plants used were propagated by spores. The evaluations were carried out when the plants reached their reproductive stage in $3 \mathrm{~L}$ containers, except for Microgramma squamulosa and Blechnum lanceola, which was grown in $400 \mathrm{~cm}^{3}$ pots. 
Table 1. Institute of Floriculture INTA (IF) codes, species, procedencies and growth habit of 15 ferns native to Argentina.

\begin{tabular}{|c|c|c|c|}
\hline IF Codes & Species & Procedencies & Growth habits \\
\hline 20100728D2 & Adianthopsis radiata (L.) Fée & Dpto. Montecarlo, Misiones & $\mathrm{T}$ \\
\hline $20101126 \mathrm{E} 1$ & Anemia tomentosa (Savigny) Sw. & Dpto. Monteros, Tucumán & $\mathrm{T}$ \\
\hline $20100801 \mathrm{E} 1$ & Asplenium auritum $\mathrm{Sw}$. & Dpto. Oberá, Misiones & E R \\
\hline 20101126A2 & $\begin{array}{c}\text { Blechnum austrobrasilianum } \\
\text { de la Sota }\end{array}$ & Dpto. Monteros, Tucumán & $\mathrm{T}$ \\
\hline $20090611 \mathrm{C} 1$ & $\begin{array}{l}\text { Blechnum brasiliense } \\
\text { Desv. var. brasiliense }\end{array}$ & Dpto. Concordia, Entre Ríos & $\mathrm{T}$ \\
\hline 20100729B5 & Blechnum lanceola Sw. & Dpto. Iguazú, Misiones & T R \\
\hline $20090611 \mathrm{C} 2$ & Campyloneurum nitidum (Kaulf.) C. & Dpto. Concordia, Entre Ríos & E \\
\hline 20100728D11 & $\begin{array}{l}\text { Doryopteris nobilis } \\
\text { (T. Moore) C. Chr. }\end{array}$ & Dpto. Montecarlo, Misiones & $\mathrm{T}$ \\
\hline $20100801 \mathrm{G} 1$ & $\begin{array}{l}\text { Lomariocycas schomburgkii } \\
\text { (Klotzsch) Gasper \& A.R. Sm. }\end{array}$ & Dpto. Oberá, Misiones & $\mathrm{T}$ \\
\hline 20101126B5 & $\begin{array}{c}\text { Microgramma squamulosa } \\
\text { (Kaulf.) de la Sota }\end{array}$ & Dpto. Monteros, Tucumán & $\mathrm{E}$ \\
\hline 20100728D18 & Niphidium crassifolium (L.) Lellinger & Dpto. Montecarlo, Misiones & $\mathrm{E}$ \\
\hline $20100225 \mathrm{~A} 3$ & $\begin{array}{l}\text { Phlebodium areolatum } \\
\text { (Humb. \& Bonpl. ex Willd.) J. Sm. }\end{array}$ & Dpto. Río Seco, Tucumán & $\mathrm{E}$ \\
\hline $20170915 \times 1$ & Pityrogramma calomelanos (L.) Link & Dpto. Oberá, Misiones & $\mathrm{T}$ \\
\hline $20100225 \mathrm{~A} 2$ & Pteris deflexa Link & Dpto. Río Seco, Tucumán & $\mathrm{T}$ \\
\hline 20100729B4 & Pteris denticulata $\mathrm{Sw}$. & Dpto. Iguazú, Misiones & E \\
\hline
\end{tabular}

*According to Arana et al. (2016), T: terrestrial, E: epiphytic, R: rupicolous

\section{Ornamental Potentiality}

The quality parameters were evaluated considering the leather fern ( $R$. adiantiformis) as a reference (Verdugo et al., 2006) and other characteristics of the cut foliage. The length of the frond petiole and length and width of the frond blade were measured. Brightness and consistency of the fronds, abundance of spores, presence of pests and diseases were analysed visually. Also, frond development in one or more than one plane was record. Thirty fronds were used for the morphological characterization. These values were transferred to categories as presented in Table 2. The sum of the scores reached a maximum value of 21 for the best condition. For the vase life another 20 points were considered, since it is an essential characteristic for cutting foliage aptitude. 
Table 2. Attributes of frond quality of ferns native to Argentina.

\begin{tabular}{|c|c|c|c|c|}
\hline \multicolumn{1}{|c|}{ Descriptors } & \multicolumn{4}{|c|}{ Scores } \\
\hline & $\mathbf{1}$ & $\mathbf{2}$ & $\mathbf{3}$ \\
\hline A. Frond petiole length $(\mathrm{cm})$ & $\leq 5$ & $5-15$ & $>15$ \\
\hline B. Frond blade lenght $(\mathrm{cm})$ & short $(\leq 40)$ & medium $(40-55)$ & long $(>55)$ \\
\hline C. Frond blade width $(\mathrm{cm})$ & $\leq 15$ & $15-255$ & $>25$ \\
\hline D. Planes & more than 1 & 1 & \\
\hline E. Brightness & No & Yes & coriaceous & no dirty \\
\hline F. Consistency & no coriaceous & semi coriaceous & \\
\hline G. Spores abundance & dirty the frond & moderately dirty & & \\
\hline H. Presence of pests and & yes & no & large $(11 \sim 20)$ & very large $(>20)$ \\
\hline diseases & score: 15 & score: 20 \\
\hline
\end{tabular}

For the determination of the vase life, homogeneous fronds were selected; the basal $2 \mathrm{~cm}$ were cut and placed in 250,500 and $100 \mathrm{~mL}$ containers depending on the size of the plant materials to be evaluated, with distilled water immediately after being harvested. The upper part of the containers was covered with film to avoid the loss of water by evaporation. The film was perforated to place the fronds. Three vases were used per species with three fronds each, and the test was carried out in triplicate, in a postharvest room $\left(18^{\circ} \mathrm{C}, 64 \% \mathrm{RH}, 700 \mathrm{lux}\right)$.

The variation in the external appearance of the fronds was recorded daily, in order to determine the end of the vase life. It was determined by the occurrence of some symptom that indicated a loss of quality and that made it impossible to fulfil its ornamental function, such as wilting and / or yellowing and / or curving of the fronds.

The ornamental potential was defined by the sum of the scores.

\section{Productivity of selected species}

The production of fronds of six selected species with good scores was recorded. Despite $M$. squamulosa and $A$. auritum showed very good vase life, they were discarded in this experiment due to the small sizes of the fronds. The arborescent habit of L. schomburgkii was considered not suitable for cut foliage production and it was also discarded.

Once the plants had a size according to a $3 \mathrm{~L}$ pot, 12 plants per species were planted in 2 batches of 6 plants, in $90 \mathrm{~cm}$ wide ridges and staggered at a distance of 45 $\mathrm{cm}$, in a greenhouse with $10{ }^{\circ} \mathrm{C}$ minimum temperature control (Figure 1A). A 50\% shading mesh was placed that covered the roof and the sides of the trial. The substrate was a recycled with the addition of $40 \%$ bark to generate aeration. Irrigation was manual and biweekly fertilizations were carried out with a 15:15:15 NPK fertilizer.

Mature fronds were collected, the number of fronds per plant was counted in the second year of cultivation and the fronds production per square meter was calculated. Petiole length and blade length and width of 30 fronds were measured. The data were statistically analysed with an analysis of variance and Fisher's test with the statistical program Infostat 2009 (Di Rienzo et al., 2011).

\section{Results and Discussion}

\section{Ornamental Potentiality}

The evaluation of ornamental potentiality through morphological descriptors and vase life is presented in ascending order in Table 3. Phlebodium areolatum, $N$. crassifolium and C. nitidum stood out with values of 37 , 36 and 35, respectively. Phlebodium areolatum retained its appearance in vase for 26 days (Figure 2), and its large fronds with a developed petiole gave it interesting properties. The petiole is curved, so it is suggested for pendulous arrangements. 


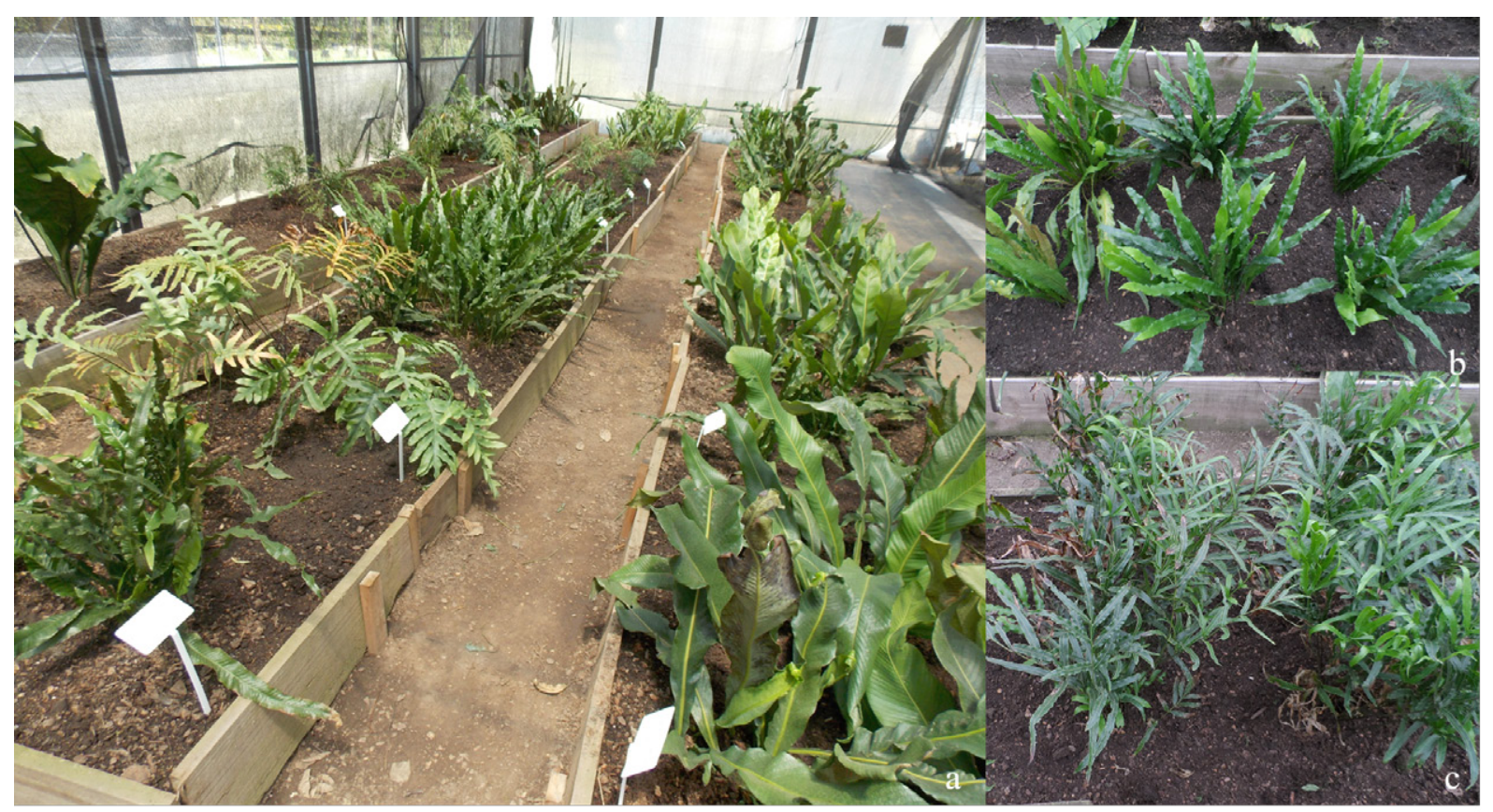

Figure 1. Production of native ferns: a: general view of beds; b. Campyloneurum nitidum; c. Pteris denticulata.

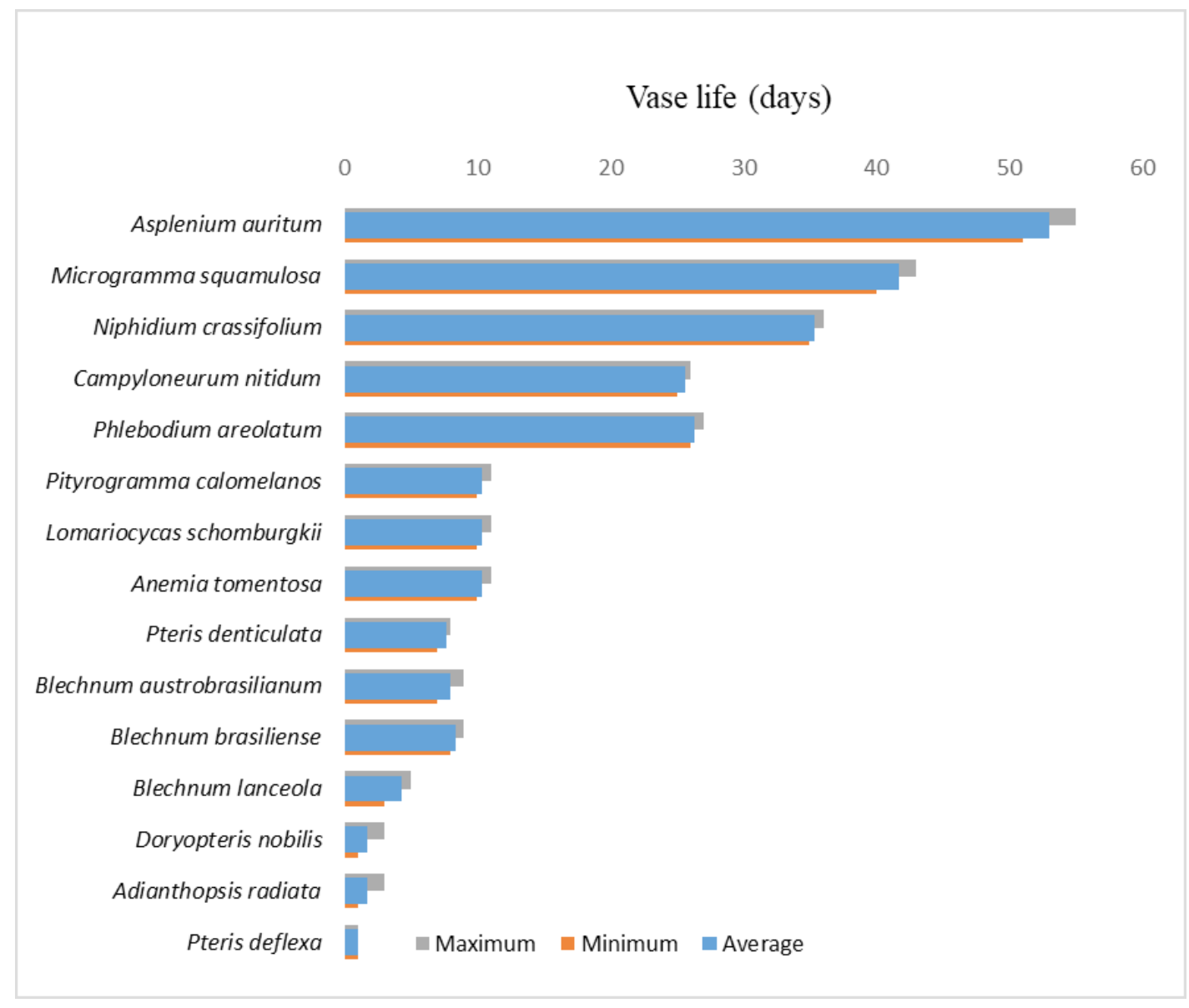

Figure 2. Vase life (days) of 15 ferns native to Argentina values of three experiments. 
Campyloneurum nitidum presented a very high vase longevity, more than 30 days (Figure 2), and also presented high values in other important characteristics such as frond length, leathery consistency, absence of pests and diseases and spores that do not make dirty the fronds. The morphology of the frond in one plane is interesting because it is suitable for the transport in boxes (Figure1B). Preparation of cut flowers and foliages is a tedious job and require specific packaging for each species (Ahmad et al., 2021).

Niphidium crassifolium excelled for its vase life of 36 days long fronds and, as C. nitidum, in one plane.

Microgramma squamulosa reached a score of 35 value that positions it, together with the previous species, as a potential new crop as cut foliage, although the size of its fronds is small depending on the quality standards of ferns. Despite of this, it could be used for small bouquets or other non-traditional arrangements.

These four species are epiphytes, so they could have low nutritional and water requirements. Epiphytic ferns grow naturally in soilless condition, without using the typical water and nutrient storage of soil and typically have adaptations to endure periods of desiccation (Anderson, 2021) Microgramma has stout suberified stems storing water and amylaceus reserves (Dubuisson et al., 2009). It is interesting to mention here that in phylogenetic studies, Labiak and Moran (2018) confirm that Campyloneurum forms a clade with Microgramma and Niphidium.
The species that presented a short vase life, $P$. deflexa, $A$. radiata, $D$. nobilis and $B$. lanceola, were discarded as possible candidates for cut foliage crops. A long vase life is the main attribute that a species must have to be used as cut foliage, and like cut flowers, it should remain vigorous and attractive for at least 10 days (Weiss, 2002). In these cases, fronds longevity was less than 5 days (Figure 2).

Blechnum brasiliense, $B$. austrobrasilianum, $P$. denticulata, A. tomentosa, L. schomburgkii and $P$. calomelanos presented medium vase life that was later reflected in intermediate scores. These ferns can be subjected to trials to improve longevity using different vase solutions, in order to maximize the quality and facilitate commercialization. The use of floral preservatives has been found to influence to a great extent, it can offer at least double longevity of cut flowers and foliages duo (Malakar et al., 2017). Furthermore, dehydration methods, like glycerinization, were developed for cut foliage (Jhanji et al., 2018).

The indicators of end of vase life differed among species (Table 3). Wilting, curving, yellowing and/or loss of brightness of fronds were the symptoms of senescence observed. In some species used as cut foliage, the rate of water absorption is less than the rate of transpiration; this leads to leaf wilting, destroys or disrupts its physical structures, and causes activity imbalances in macromolecules and organelles (Teerarak and Laosinwattana, 2019).

Table 3. Scores of ornamental attributes of 15 ferns native to Argentina, sum of scores and indicators of end of vase life.

\begin{tabular}{|c|c|c|c|c|c|c|c|c|c|c|c|}
\hline \multirow{2}{*}{ Species } & \multicolumn{9}{|c|}{ Scores } & \multirow{2}{*}{$\begin{array}{c}\text { SUM } \\
\text { of } \\
\text { scores }\end{array}$} & \multirow{2}{*}{$\begin{array}{c}\text { Indicators of end of } \\
\text { vase life }\end{array}$} \\
\hline & $\mathbf{A}$ & B & $\mathbf{C}$ & D & $\mathbf{E}$ & $\mathbf{F}$ & $\mathbf{G}$ & $\mathbf{H}$ & I & & \\
\hline Blechnum lanceola & 1 & 1 & 1 & 2 & 2 & 3 & 3 & 2 & 0 & 15 & wilting, curving \\
\hline Adianthopsis radiata & 3 & 2 & 3 & 1 & 1 & 2 & 3 & 2 & 0 & 17 & wilting, curving \\
\hline Doryopteris nobilis & 3 & 2 & 2 & 2 & 2 & 3 & 3 & 1 & 0 & 18 & $\begin{array}{l}\text { yellowing, } \\
\text { curving }\end{array}$ \\
\hline Blechnum brasiliense & 1 & 3 & 2 & 2 & 2 & 3 & 3 & 2 & 0 & 18 & wilting, curving \\
\hline Pteris deflexa & 3 & 3 & 3 & 1 & 2 & 1 & 3 & 2 & 0 & 18 & wilting, curving \\
\hline Anemia tomentosa & 3 & 1 & 1 & 2 & 1 & 1 & 3 & 1 & 10 & 23 & wilting, curving \\
\hline Blechnum austrobrasilianum & 2 & 1 & 1 & 2 & 1 & 2 & 3 & 2 & 10 & 24 & wilting \\
\hline Pteris denticulata & 3 & 2 & 2 & 1 & 2 & 2 & 3 & 2 & 10 & 27 & $\begin{array}{l}\text { wilting, curving, loss } \\
\text { of brightness }\end{array}$ \\
\hline Lomariocycas schomburgkii & 1 & 3 & 2 & 2 & 1 & 3 & 3 & 2 & 10 & 27 & wilting, curving \\
\hline Pityrogramma calomelanos & 3 & 2 & 2 & 2 & 2 & 2 & 3 & 2 & 10 & 28 & wilting, curving \\
\hline Asplenium auritum & 2 & 1 & 1 & 2 & 1 & 2 & 3 & 2 & 10 & 34 & wilting, curving \\
\hline Microgramma squamulosa & 1 & 1 & 1 & 2 & 2 & 3 & 3 & 2 & 20 & 35 & $\begin{array}{l}\text { wilting, loss of } \\
\text { brightness }\end{array}$ \\
\hline Campyloneurum nitidum & 1 & 3 & 1 & 2 & 2 & 3 & 1 & 2 & 20 & 35 & $\begin{array}{c}\text { wilting, loss of } \\
\text { brightness }\end{array}$ \\
\hline Niphidium crassifolium & 1 & 3 & 1 & 2 & 2 & 2 & 3 & 2 & 20 & 36 & $\begin{array}{c}\text { wilting, loss of } \\
\text { brightness }\end{array}$ \\
\hline Phlebodium areolatum & 3 & 3 & 3 & 2 & 1 & 1 & 2 & 2 & 20 & 37 & yellowing,curving \\
\hline
\end{tabular}

A. Petiole length, B. Blade length, C. Blade width, D. Plane, E. Brightness, F. Consistency, G. Spores abundance, H. presence of pest and diseases, I. Vase longevity 
It is interesting to consider the frond form variability obtained for flower arrangement according to Stamps classification of greens (1987) as linear like in Aspidistra, mass material in Pittosporum, filler in Asparagus, and distintictive like in palms. Here, it is represented as linear in B. lanceola, A. radiata, D. nobilis, B. brasiliense and $T$. deflexa; mass material in A.tomentosa, B. austrobrasilianum, N. crassifolium, A. auritum, P. denticulata, L. schomburgkii and $P$. calomelanos; filler material in $M$. squamulosa and $P$. areolatum; and a distintictive shape in C. nitidum.

\section{Productivity of selected species}

The production of fronds per plant of the species selected by the highest scores is presented in Table 4. It is important to mention that the ferns that are grown for cut foliage begin to be productive in the second year after implantation, approximately.

The production of $C$. nitidum stood out, producing 82.08 fronds per plant, which translates into 273.61 fronds $\mathrm{m}^{-2}, P$. denticulata produced 179.44 fronds $\mathrm{m}^{-2}$ (Figure $1 \mathrm{C}$ ) and $N$. crassifolium 136.66 fronds $\mathrm{m}^{-2}$ (Table 4 ).

Table 4. Production of selected fern fronds after 24 months of cultivation in beds.

\begin{tabular}{|c|c|c|c|c|c|c|}
\hline Species & Fronds/plant $\mathbf{N}^{\circ}$ & $\begin{array}{c}\text { Total } \\
\mathbf{N}\end{array}$ & $\begin{array}{c}\text { Fronds } \\
\mathbf{N} / \mathbf{m}^{\mathbf{2}}\end{array}$ & $\begin{array}{c}\text { Peliote length } \\
\mathbf{( c m )}\end{array}$ & $\begin{array}{c}\text { Blade lengh } \\
\mathbf{( c m )}\end{array}$ & $\begin{array}{c}\text { Blade width } \\
\mathbf{( c m})\end{array}$ \\
\hline Pityrogramma calomelanos & $29.75 \pm 23.12 \mathrm{a}$ & 357 & 99.16 & $17.69 \pm 2,65$ & $49.59 \pm 4.46$ & $24 \pm 2.24$ \\
\hline Niphidium crassifolium & $41.00 \pm 8.33 \mathrm{ab}$ & 492 & 136.66 & 0 & $51.71 \pm 9,29$ & $8.62 \pm 1.10$ \\
\hline Campyloneurum nitidum & $82.08 \pm 26.09 \mathrm{c}$ & 985 & 273.61 & 0 & $52,19 \pm 7.80$ & $4.10 \pm 0.55$ \\
\hline Blechnum austrobrasilianum & $29.83 \pm 11.53 \mathrm{a}$ & 358 & 99.44 & $12.40 \pm 3.39$ & $35.09 \pm 5.26$ & $6.71 \pm 1,44$ \\
\hline Pteris denticulata & $53.83 \pm 13.36 \mathrm{~b}$ & 646 & 179.44 & $34.78 \pm 10.30$ & $61.66 \pm 14.86$ & $24.57 \pm 4.96$ \\
\hline Phlebodium areolatum & $15.5 \pm 5.5 \mathrm{~d}$ & 186 & 51.60 & $43.47 \pm 5.54$ & $90.32 \pm 12.57$ & $32.45 \pm 5.48$ \\
\hline
\end{tabular}

Considering that the leather fern ( $R$. adiantiformis) produces 114 fronds per square meter in the second year in cultivation (Chahin and Azocar, 2012), the mentioned species exceeded this value, so they could potentially be competitive crops. Pityrogramma calomelanos and B. austrobrasilianum produced 99.66 and 99.44 fronds $\mathrm{m}^{-2}$ respectively, values also near those mentioned for $R$. adiantiformis.

Phlebodium areolatum produced only 51.6 fronds $\mathrm{m}^{-2}$, this low productivity, as well as the difficulty of its cultivation due to the little rigid petioles, do not make it suitable for bed production as cut foliage, despite the long postharvest life. Nevertheless, some methods for conducting the production could be analysed.

It is also important to mention that the reference value comes from outdoor crops with shading mesh, and in this case the experiment was carried out in a greenhouse, a probable reason for the higher productivity found. Besides, in this study the cultivation was initiated with already developed plants, in commercial crops many times it begins with pieces of rhizomes.

According to Strandberg (2003), frond production and development rates of $R$. adiantiformis varied greatly with the seasons and were strongly associated with weather variables, but significant rate fluctuation unrelated to weather were also detected. Therefore, it is probably that the production of the studied ferns could be considered for other production sites.

Compared with the values of the quality standards for internal use and export of fronds of $R$. adiantiformis according to Verdugo et al. (2006), being the minimum length $40 \mathrm{~cm}$ and the optimum $55 \mathrm{~cm}$, the selected ferns presented values within or exceeding that range (Table 4). Phlebodium areolatum and $P$. denticulata had the longest fronds with petioles of $34.78 \mathrm{~cm}$ and $43.47 \mathrm{~cm}$ and blade length of $61.66 \mathrm{~cm}$ and $90.32 \mathrm{~cm}$, respectively.

Despite $N$. crassifolium and C. nitidum do not have a developed petiole, they reached the reference value and provide a different morphology from that available in the markets. Blechnum austrobrasilianum had the shortest fronds but also within the accepted range in markets.

The present work showed that it is feasible to consider the commercial production of $P$. calomelanos, $N$. crassifolium, C. nitidum, B. austrobrasilianum and $P$. denticulata by the quantity of fronds obtained and their quality represented by their size. It would be important to continue the studies to determine the maximum production period. Campyloneurum nitidum and P. denticulata stood out as the most productive species in the period tested. Inclusion of new species in cultivation also promote ex situ conservation of biodiversity and sustainable use, preventing extractive practices. Many other ferns of Argentine are still to be prospected and the protocol proposed can be an alternative to evaluate them.

\section{Conclusions}

Ferns species were selected objectively for their aptitude to be used as cut foliage through morphological attributes, vase life and fronds production. Campyloneurum nitidum and $P$. denticulata stood out for their frond production. 


\section{Author Contribution}

GF: Conceived and designed the analysis, collection in the wild, collected data and wrote the paper. MJP: cultivate ferns and collected data of production of fronds. AP: collected vase life experiment data. MS: collection in the wild, taxonomic identification of ferns.

\section{References}

AHMAD, I.; DOLE, J.M.; MALIK, A.U.; KHAN, A.S. Postharvest Handling of Ornamentals. In: KHAN, A.S., ZUIAF, K. Floriculture Industry: shifting directions, new trends, and future prospect. Faisalabad: University of Agriculture, 2021. p.461-462.

ANDERSON, O.R. Physiological ecology of ferns: Biodiversity and conservation perspectives. International Journal of Biodiversity and Conservation, v.13, n.2, p.49-63, 2021. https://doi.org/10.5897/IJBC2021.1482

ARANA, M.D.; PONCE, M.M.; ZULOAGA, F.O.; BELGRANO, M.J. Licófitas, helechos y gimnospermas. Flora Vascular de la República Argentina. v.2. San Isidro: Instituto de Botánica Darwinion, 2016. 448p.

BECKMANN-CAVALCANTE, M.Z;; SABINO, J.H.F.; BARBOSA, M.S.M.; DULTRA, D.F.S.; SILVA, H.L.C.; SILVA, S.D.P.; STUMPF, E.R.T. Innovation in floriculture with ornamental plants from Caatinga biome. Ornamental Horticulture, v.23, n.3, p.289-295, 2017.

CHAHIN, A., AZOCAR, G. Experiencia en la Región de La Araucania. Cultivo de follajes ornamentales: Una alternativa para la floricultura del sur. Temuco: Boletín INIA - Instituto de Investigaciones Agropecuarias, 2012. 142p.

DI RIENZO, J.A.; CASANOVES, F.; BALZARINI, M.G.; GONZALEZ, L.; TABLADA, M., ROBLEDO, C.W. InfoStat, FCA. Córdoba: Universidad Nacional de Córdoba, 2011.

DUBUISSON, J.-Y.; SCHNEIDER, H.; HENNEQUIN, S. Epiphytism in ferns: diversity and history. Comptes Rendus Biologies, v.332, n.2-3, p.120-128, 2009.

FACCIUTO, G.; SANCHEZ, M., PANNUNZIO, M.J. 2014. Helechos nativos de Argentina. Available at: $<$ http:// procadisaplicativos.inta.gob.ar/cursosautoaprendizaje/ helechos/index.html> Acessed: Aug 31 2021.

BENAVENTE-GARCIA, A.G; BAÑON, S.; FERNÁNDEZ, J.A. Cultivos ornamentales para complementos del ramo de flor. Madrid: Mundi-Prensa, 1998. 228p.

GUTIÉRREZ, I.C.; GUARÍN, S.; RODRIGUEZ, L.E. Prospección y evaluación de especies con potencial de follaje para la elaboración de bouquets. Revista Agronomía Colombiana, v.25, n.1, p. 176-188, 2007.
JHANJI, S.; DHATT, K.K.; SINGH, P. Improving the shelf life of cut foliage through glycerinization. Indian Journal of Horticulture, v.75, n.4, p.690-697, 2018.

KUMAR, A.; FERNANDEZ, H. Recent advances in fern research: a brief review. Indian Fern Journal, v.36, p.110$132,2019$.

LABIAK, P.H.; MORAN R.C. Phylogeny of Campyloneurum (Polypodiaceae). International Journal of Plant Science, v.179, n.1, p.36-41, 2018.

MALAKAR M.; ACHARYYA P.; BISWAS S. Effect of certain chemicals on post-harvest life of some cut foliages. International Journal of Agriculture, Environment and Biotechnology Citation, v.10, n.2, p.199-207, 2017. https://doi.org/10.5958/2230-732X.2017.00023.7

PONCE, M.; KLAUS MEHLTRETER, K.; DE LA SOTA, E.R. Análisis biogeográfico de la diversidad Pteridofítica en Argentina y Chile continental. Revista Chilena de Historia Natural, v.75, p.703-717, 2002.

SAFEENA S.A.; THANGAM, M.; SINGH, N.P. Conservation and evaluation of different cut foliage species comprising pteridophytes (ferns and fern allies) of west coast regions of India. Journal Indian Society Coastal Agricultural Research, v.37, n.1, p.7-13, 2019.

SANKAR, M.; SUDHADEVI, P.K.; GEETHA C.K.; ROSHMI, K.; SHILPA P. Performance evaluation of ferns for cut green and landscape purpose. Journal of Horticultural Sciences, v.14, n. 2, p.137-141, 2019.

SINGH, A.P.; JOHARI, D. Scope of ferns in horticulture and economic development. In: Fernández, H. Current Advances in Fern Research. Cham: Springer, 2018. p.153-175.

STAMPS, R. Vase life characteristics of fern. Acta Horticulturae, v.755, p.155-162, 2007.

STAMPS, R.H. Major Florida cut foliage crops classified according to floral design and landscape usage. Proceedings of the Florida State Horticultural Society, v.100, p.179$180,1987$.

STRANDBERG, O.J. Seasonal variations in production and development of leatherleaf fern leaves. Annals of Applied Biology, v.143, p.235-243, 2003.

STUMPF, E.R.T.; HEIDEN, G.; BARBIERI, R.L.; FISCHER, S.Z.; NEITZKE, R.S.;ZANCHET, B.; GROLLI, E.R. Método para avaliação da potencialidade ornamental de flores e folhagens de corte nativas e não convencionais. Revista Brasileira de Horticultura Ornamental, v.13, n. 2, p.143-148, 2007. 
TEERARAK, M.; LAOSINWATTANA, C. Essential oil from ginger as a novel agent in delaying senescence of cut fronds of the fern (Davallia solida (G. Forst.) Sw.). Postharvest Biology and Technology, n.156, 2019. https://doi.org/10.1016/j.postharvbio.2019.06.001

VERDUGO, G.; BIGGI, M.A., MONTEISNOS, A., SORIANO, C.; CHAHÍN, G. Manual de Poscosecha de Flores. Valparaiso: Pontificia Universidad Católica de Valparaíso. Fundación para la Innovación Agraria, 2006. 76p.
WEISS, D. Introduction of new cut flowers: domestication of new species and introduction of new traits not found in commercial varieties. In: VAINSTEIN, A. Breeding for Ornamentals: classical and molecular approaches. Netherlands: Springer, 2002. p.129-137. 